\title{
PENGARUH SISTEM INFORMASI AKUNTANSI PENJUALAN DAN PERSEDIAAN BARANG DAGANG BERBASIS CLIENT SERVER TERHADAP KINERJA KARYAWAN CIPTO JAYA SADEL LAMONGAN
}

\author{
Nanang Hidayat \\ Universitas Islam Lamongan
}

\begin{abstract}
ABSTRAK
Penerapan suatu sistem informasi yang baik diharapkan dapat meminimalisir kesalahan yang terjadi dan mendukung kegiatan perusahaan yang bertujuan untuk mengembangkan dan meningkatkan kualitas informasi perusahaan. Sistem informasi baik secara langsung maupun tidak langsung akan mempengaruhi kinerja karyawan. Tujuan dari penelitian ini adalah untuk menganalisis dan menguji pengaruh sistem informasi akuntansi penjualan dan persediaan barang dagang berbasis client server terhadap kinerja karyawan pada Cipto Jaya Sadel Lamongan. Jenis penelitian menggunakan penelitian kuantitatif, populasi dalam penelitian ini adalah pemilik, seluruh karyawan, dan seluruh pelanggan, sedangkan sampel yang digunakan adalah pemilik, sebagian karyawan berjumlah 3 orang, dan 6 orang pelanggan dipilih secara acak. Data dikumpulkan menggunakan kuesioner yang diberikan kepada 10 responden. Teknik analisis regresi linier sederhana digunakan pada penelitian ini. Berdasarkan hasil penelitian dapat diambil kesimpulan bahwa sistem informasi akuntansi penjualan dan persediaan barang dagang berbasis client server tidak berpengaruh signifikan terhadap kinerja karyawan pada Cipto Jaya Sadel Lamongan. Hal ini terjadi karena karyawan-karyawan masih belum memiliki keahlian yang cukup untuk menjalankan sistem informasi tersebut. Untuk peniliti selanjutnya yang tertarik dengan penelitian ini agar mempertimbangkan faktor-faktor lain yang mempengaruhi seperti menambah jumlah reponden, jumlah pernyataan kuesioner, dan variabel lainnya. Sehingga penelitian akan menjadi lebih baik.
\end{abstract}

Kata kunci : Client Server, Kinerja, , Regresi Linier Sederhana, Sistem Informasi Akuntansi

\section{PENDAHULUAN}

Pada saat ini dimana teknologi informasi berkembang dengan sangat pesat dan berpengaruh dalam banyak segi, salah satunya adalah dari segi ekonomi dan juga bisnis. Seiring berkembangnya zaman, pemilik usaha dituntut untuk dapat bersaing dalam meningkatkan mutu pelayanan dan kualitas kerja perusahaan. Dengan menerapkan suatu sistem informasi yang baik diharapkan dapat meminimalisir kesalahan yang terjadi dan mendukung kegiatan perusahaan yang bertujuan untuk mengembangkan dan meningkatkan kualitas informasi perusahaan. Pada penelitian Hidayat (2018) yaitu menganalisis pengembangan sistem informasi akuntansi penjualan dan persediaan 
barang dagang berbasis client server pada Cipto Jaya Sadel Lamongan untuk mengetahui pengembangan dari sistem manual menjadi sistem informasi berbasis komputer yang dilakukan oleh pemilik toko dan menganalisis keunggalan dan kelemahan dari pengembangan sistem informasi tersebut.

Penerapan sistem informasi penjualan dan persediaan barang dagang berbasis client server akan mempengaruhi kinerja karyawan pada Cipto Jaya Sadel Lamongan, baik secara langsung maupun tidak langsung. Kinerja merupakan penampilan hasil kerja pegawai baik secara kuantitas maupun kualitas (Cokroaminoto, 2007). Kinerja yang baik dapat dilihat dari hasil kerja yang dicapai oleh setiap karyawan dalam melaksanakan tugas-tugas yang diberikan atas dasar kecakapan, pengalaman, serta keterampilan yang digunakan oleh karyawan dalam menyelesaikan setiap pekerjaannya. Menurut Jumaili (2005) pencapaian kinerja individu berkaitan dengan pencapaian serangkaian tugas-tugas individu dengan dukungan teknologi informasi yang ada. Dengan adanya kesesuaian antara sistem informasi penjualan dan persediaan barang dagang berbasis client server yang telah dikembangkan pada Cipto Jaya Sadel Lamongan dengan tugas, kebutuhan, dan kemampuan setiap karyawan dalam toko tersebut diharapkan terjadinya pencapaian kinerja. Keberhasilan sebuah sistem informasi tersebut dijalankan dan memberikan dampak yang positif bagi penggunanya.

Dari uraian latar belakang di atas, maka peneliti membuat rumusan masalah penelitian yaitu "Apakah sistem informasi akuntansi penjualan dan persediaan barang dagang berbasis client server yang telah dikembangkan dapat mem-pengaruhi kinerja karyawan Cipto Jaya Sadel pada Lamongan ?’. Tujuan penelitian ini adalah untuk menganalisis dan menguji pengaruh sistem informasi akuntansi penjualan dan persediaan barang dagang berbasis client server terhadap kinerja karyawan pada Cipto Jaya Sadel Lamongan.

\section{METODE PENELITIAN}

Peneliti menggunakan jenis penelitian kuantitatif berupa skor atas jawaban yang diberikan oleh responden terhadap pertanyaan-pertanyaan yang ada pada kuesioner. Metode kuantitatif adalah metode yang digunakan untuk penyajian hasil penelitian dalam bentuk angka-angka atau statistik (Sugiyono, 
2014). Kuesioner merupakan daftar pertanyaan yang diberikan kepada orang lain yang bersedia mem-berikan respon sesuai dengan permintaan pengguna (Suharsimi Arikunto, 2002). Populasi dalam penelitian ini adalah pemilik, seluruh karyawan dan seluruh pelanggan Cipto Jaya Sadel. Sampel dalam penelitian ini adalah pemilik, sebagian dari karyawan berjumlah 3 orang, dan 6 orang pelanggan yang dipilih secara acak. Teknik peng-ambilan sampel yang digunakan adalah purposive sampling, teknik untuk menentukan sampel penelitian dengan beberapa pertimbangan ter-tentu (Sugiyono, 2010). Kriteria pengambilan sampel yaitu seseorang yang bertanggung jawab dan bersangkutan dengan penggunaan sistem informasi tersebut .

Jenis data yang digunakan dalam penelitian ini adalah data primer dan data sekunder. Data primer berupa kuesioner yang di-berikan secara langsung kepada responden. Data sekunder dalam penelitian ini diperoleh melalui jurnal, skripsi, buku, dan literatur lainnya yang berkaitan dengan penelitian ini. Metode pengumpulan data dalam penelitian ini adalah menggunakan angket atau kuesioner, observasi, dan dokumentasi.
Dalam penelitian ini variabel yang digunakan yaitu variabel bebas Sistem Informasi Akuntansi Penjualan dan Persediaan Barang Dagang, dan variabel terikat Kinerja Karyawan. Menurut Bodnar dan Hopwood (2010), sistem informasi akuntansi merupakan suatu kumpul-an dari berbagai macam sumber daya, seperti manusia dan juga peralatan yang dirancang untuk meng-ubah data keuangan dan juga data lainnya menjadi sebuah informasi yang berguna bagi user dan peng-gunanya. Penjualan adalah kegiatan manusia yang mengarahkan untuk memenuhi dan memuaskan ke-butuhan dan keinginan melalui proses pertukaran (Assuari, 2004). Persediaan adalah barang-barang yang dimiliki atau disimpan di perusahaan yang terdiri dari produk jadi, produk dalam proses, bahan baku, bahan penolong, bahan habis pakai, dan suku cadang yang dimaksudkan untuk dijual kembali (Mulyadi, 2001). Menurut Syafrizal (2005) client server adalah jaringan komputer dengan komputer yang didedikasikan khusus sebagai server, sebuah service atau layanan bisa diberikan oleh sebuah komputer atau lebih. Menurut Cokroaminoto (2007) Kinerja merupakan penampilan hasil 
kerja pegawai baik secara kuantitas maupun kualitas.

Adapun tahap-tahap analisis dalam penelitian ini meliputi, (1) Menganalisis Pengaruh Sistem Informasi Akuntansi Penjualan dan Persediaan Barang Dagang berbasis Client Server terhadap Kinerja Karyawan pada Cipto Jaya Sadel Lamongan menggunakan alat pengukuran data dari hasil penyebaran angket atau kuesioner yang meng-gunakan skala Likert. (2) Mengolah data dari hasil kuesioner ke dalam program SPSS.

Pengujian validitas dan reliabilitas dilakukan terlebih dahulu untuk mengetahui sejauh mana alat ukur yang telah ditentukan bisa dipercaya dan digunakan sebagai alat pengukur. Kemudian uji asumsi klasik dilakukan untuk mengetahui bahwa model terbebas dari masalah normalitas data dan multikolinieritas.

Teknik analisis data yang digunakan adalah teknik analisis regresi linier sederhana, yang peng-olahannya dengan menggunakan software IBM (SPSS). Dalam me-lakukan penelitian ini peneliti menyebar angket atau kuesioner kepada pemilik, sebagian karyawan, dan sebagian pelanggan Cipto Jaya Sadel Lamongan. Angket atau kuesioner dibagi menjadi dua, yang pertama adalah pertanyaan mengenai sistem informasi akuntansi penjualan dan persediaan barang dagang berbasis client server.

\section{HASIL PENELITIAN DAN PEMBAHASAN}

Analisis data dalam penelitian ini terdiri dari beberapa tahapan uji, yang menggunakan alat bantu aplikasi program SPSS. Sampel dalam penelitian ini adalah pemilik, sebagian karyawan, dan sebagian pelanggan yang dipilih secara acak dengan jumlah keseluruhan 10 orang. Data kuesioner yang telah disebar untuk diisi, kembali dan dapat diolah dengan 10 kuesioner. Berikut ini adalah hasil penyebaran kuesioner yang disajikan pada Tabel 1. 
Tabel 1. Rekapan Tanggapan Responden Terhadap Sistem Informasi Akuntansi Penjualan dan Persediaan Barang Dagang berbasis Client Server pada Cipto Jaya Sadel Lamongan

\begin{tabular}{|c|l|c|}
\hline No & \multicolumn{1}{|c|}{ Pernyataan } & Mean \\
\hline 1. & $\begin{array}{l}\text { Sistem Informasi Akuntansi Penjualan dan Persediaan } \\
\text { yang ada, sesuai dengan kebutuhan Cipto Jaya Sadel dan } \\
\text { harapan pelanggannya saat membeli barang/jasa. }\end{array}$ & 4,10 \\
\hline 2. & $\begin{array}{l}\text { Sistem Informasi Akuntansi Penjualan dan Persediaan } \\
\text { membuat pelayanan menjadi lebih cepat dan akurat. }\end{array}$ & 4,00 \\
\hline 3. & $\begin{array}{l}\text { Sistem Informasi Akuntansi Penjualan dan Persediaan } \\
\text { mudah dipahami dan digunakan. }\end{array}$ & 4,20 \\
\hline 4. & $\begin{array}{l}\text { Sistem Informasi Akuntansi Penjualan dan Persediaan } \\
\text { dapat menghasilkan informasi terbaru dengan tepat waktu }\end{array}$ & 4,00 \\
\hline 5. & $\begin{array}{l}\text { Sistem Informasi Akuntansi Penjualan dan Persediaan } \\
\text { dapat menghasilkan data yang relevan }\end{array}$ & 4,50 \\
\hline 6. & $\begin{array}{l}\text { Sistem Informasi Akuntansi Penjualan dan Persediaan } \\
\text { lebih baik dari sistem sebelumnya }\end{array}$ & 4,10 \\
\hline $\begin{array}{l}\text { Mean Secara Keseluruhan Variabel Sistem Informasi Akuntansi } \\
\text { Penjualan dan Persediaan Barang Dagang berbasis Client Server } \\
\text { (X) }\end{array}$ & 4,15 \\
\hline
\end{tabular}

Pada Tabel 1 dapat diambil sangat setuju dengan pernyataan "Sistem kesimpulan bahwa variabel Sistem Informasi Akuntansi Pen-jualan dan Informasi Akuntansi Penjualan dan Persediaan dapat meng-hasilkan data Persediaan Barang Dagang berbasis yang relevan” memiliki nilai rata-rata Client Server (X) rata-rata tertinggi 4,50 . jawaban atas responden menyatakan

Tabel 2. Rekapan Tanggapan Responden Terhadap Kinerja Karyawan

\begin{tabular}{|c|l|c|}
\hline No & \multicolumn{1}{|c|}{ Pernyataan } & Mean \\
\hline 1. & $\begin{array}{l}\text { Pekerjaan dapat diselesaikan tepat waktu setelah adanya Sistem Informasi } \\
\text { Akuntansi Penjualan dan Persediaan Barang Dagang berbasis Client Server. }\end{array}$ & 4,20 \\
\hline 2. & $\begin{array}{l}\text { Karyawan selalu mengerjakan tugas sesuai dengan kualitas yang diinginkan } \\
\text { oleh Cipto Jaya Sadel dengan penuh rasa tanggung jawab. }\end{array}$ & 4,00 \\
\hline 3. & $\begin{array}{l}\text { Pekerjaan karyawan menjadi lebih efektif setelah adanya Sistem Informasi } \\
\text { Akuntansi Penjualan dan Persediaan Barang Dagang berbasis Client Server. }\end{array}$ & 4,10 \\
\hline 4. & $\begin{array}{l}\text { Hasil dari pekerjaan yang diberikan karyawan menjadi lebih baik setelah } \\
\text { adanya Sistem Informasi Akuntansi Penjualan dan Persediaan Barang } \\
\text { Dagang berbasis Client Server. }\end{array}$ & 4,50 \\
\hline 5. & $\begin{array}{l}\text { Karyawan memberikan kepuasan kepada pelanggan setelah adanya Sistem } \\
\text { Informasi Akuntansi Penjualan dan Persediaan Barang Dagang berbasis } \\
\text { Client Server. }\end{array}$ & 4,10 \\
\hline 6. & $\begin{array}{l}\text { Pelayanan menjadi lebih baik setelah adanya Sistem Informasi Akuntansi } \\
\text { Penjualan dan Persediaan Barang Dagang berbasis Client Server. }\end{array}$ & 4,10 \\
\hline \multicolumn{2}{|l|}{$\begin{array}{l}\text { Mean Secara Keseluruhan Variabel Sistem Informasi Akuntansi Penjualan dan } \\
\text { Persediaan Barang Dagang berbasis Client Server (X) }\end{array}$} & 4,17 \\
\hline
\end{tabular}
Sumber : Data Olahan 
Pada Tabel 2 dapat diambil kesimpulan bahwa variabel Kinerja Karyawan (Y) rata-rata tertinggi jawaban atas responden menyatakan sangat setuju dengan pernyataan "Hasil dari pekerjaan yang diberikan karyawan menjadi lebih baik setelah adanya Sistem Informasi Akuntansi Penjualan dan Persediaan Barang Dagang berbasis Client Server" memiliki nilai rata-rata 4,50 .

\subsection{Uji Validitas}

Uji validitas adalah alat untuk menguji setiap butir pernyataan benarbenar telah mengungkapkan faktor atau indikator yang ingin diselidiki. Semakin tinggi validitas suatu alat ukur, semakin tepat alat ukur tersebut mengenai sasaran. Hasil uji validitas yang telah dilakukan adalah sebagai berikut :

Tabel 3. Hasil Uji Validitas

\begin{tabular}{|c|c|c|c|c|}
\hline \multirow{4}{*}{ Variabel } & $\begin{array}{c}\text { Per } \\
\text { nyat } \\
\text { aan }\end{array}$ & r hitung & $\begin{array}{c}\text { r } \\
\text { tabel }\end{array}$ & Ket. \\
\hline $\begin{array}{l}\text { Sistem } \\
\text { Informasi } \\
\text { Akuntansi } \\
\begin{array}{l}\text { Penjualan } \\
\text { dan }\end{array}\end{array}$ & $\mathrm{X} 1$ & 0,982 & 0,6 & Valid \\
\cline { 2 - 5 } $\begin{array}{l}\text { Persediaan } \\
\text { Barang }\end{array}$ & $\mathrm{X} 3$ & 0,988 & 0,6 & Valid \\
\cline { 2 - 5 } $\begin{array}{l}\text { Dagang } \\
\text { Berbasis } \\
\text { Client }\end{array}$ & $\mathrm{X} 4$ & 0,988 & 0,6 & Valid \\
\cline { 2 - 5 } Server (X) & $\mathrm{X} 6$ & 0,942 & 0,6 & Valid \\
\hline \multirow{2}{*}{$\begin{array}{c}\text { Kinerja } \\
\text { Karyawan }\end{array}$} & $\mathrm{Y} 1$ & 0,971 & 0,6 & Valid \\
\cline { 2 - 5 }$(\mathrm{Y})$ & $\mathrm{Y} 2$ & 0,969 & 0,6 & Valid \\
\cline { 2 - 5 } & $\mathrm{Y} 3$ & 0,983 & 0,6 & Valid \\
\cline { 2 - 5 } & $\mathrm{Y} 4$ & 0,902 & 0,6 & Valid \\
\cline { 2 - 5 } & $\mathrm{Y} 5$ & 0,983 & 0,6 & Valid \\
\cline { 2 - 5 } & $\mathrm{Y} 6$ & 0,947 & 0,6 & Valid \\
\hline
\end{tabular}

Sumber Data : SPSS
Butir-butir pernyataan dari kuesioner dinyatakan valid, jika nilai $r$ hitung $>r$ tabel. Nilai $r$ tabel untuk sampel penelitian sebesar 10 responden adalah 0,631. Berdasarkan hasil uji validitas pada Tabel 3 menunjukkan bahwa nilai $r$ tabel semua butir pernyataan lebih besar dari 0,631. Maka dapat disimpulkan bahwa butir-butir pernyataan kuesioner dinyatakan valid.

\subsection{Uji Reliabilitas}

Pengujian reliabilitas dilakukan dengan menggunakan Cronbach Alpha. Besarnya tingkat reliabilitas ditunjukkan oleh nilai koefisiennya, yaitu koefisien reliabilitas. Suatu data dikatakan reliabel jika nilai Cronbach Alpha tiap variabel > 0,6. Hasil uji reliabilitas yang telah dilakukan adalah sebagai berikut :

Tabel 4. Hasil Uji Reliabilitas

\begin{tabular}{|c|c|c|}
\hline Variabel & $\begin{array}{c}\text { Cronbach } \\
\text { Alpha }\end{array}$ & Kesimpulan \\
\hline $\begin{array}{l}\text { Sistem } \\
\text { Informasi } \\
\text { Akuntansi } \\
\text { Penjualan dan } \\
\text { Persediaan } \\
\text { Barang Dagang } \\
\text { Berbasis Client } \\
\text { Server }\end{array}$ & 0,978 & Reliabel \\
\hline $\begin{array}{l}\text { Kinerja } \\
\text { Karyawan }\end{array}$ & 0,981 & Reliabel \\
\hline
\end{tabular}

Berdasarkan Tabel 4 di atas maka dapat diambil kesimpulan bahwa data penelitian ini adalah reliabel, karena nilai Cronbach Alpha variabel Sistem Informasi Akuntansi Penjualan dan Persediaan Barang Dagang Berbasis 
Client Server dan Kinerja Karyawan menunjukkan lebih dari 0,6.

\subsection{Uji Normalitas}

Uji normalitas data dilakukan untuk menguji apakah dalam model regresi, variabel pengganggu (residual) memiliki distribusi normal dengan menggunakan uji One Sample Kolmogorov-Smirnov yang memiliki nilai signifikansi sebesar 0,05. Berikut adalah hasil dari uji normalitas yang dilakukan terhadap dua variabel penelitian pada Tabel 5

\begin{tabular}{|c|c|c|}
\hline & \multicolumn{2}{|c|}{$\begin{array}{r}\text { Unstandardized } \\
\text { Residual }\end{array}$} \\
\hline $\mathrm{N}$ & \multicolumn{2}{|r|}{10} \\
\hline \multirow{3}{*}{$\begin{array}{l}\text { Normal } \\
\text { Parameters }\end{array}$} & Mean & 0,0000000 \\
\hline & & \\
\hline & $\begin{array}{l}\text { Standard } \\
\text { Deviation }\end{array}$ & 4,88512568 \\
\hline \multirow{3}{*}{$\begin{array}{l}\text { Most Extreme } \\
\text { Differences }\end{array}$} & Absolute & 0,148 \\
\hline & Positive & 0,148 \\
\hline & Negative & $-0,140$ \\
\hline $\begin{array}{l}\text { Kolmogorov- } \\
\text { Smirnov Z }\end{array}$ & & 0,148 \\
\hline $\begin{array}{l}\text { Asymp. Sig. (2- } \\
\text { tailed) }\end{array}$ & & 0,200 \\
\hline
\end{tabular}

Hasil uji normalitas di atas menunjukkan bahwa nilai Asymp. Sig. (2-tailed) sebesar 0,200, yang artinya > 0,05. Maka dapat di-simpulkan bahwa data penelitian ini berdistribusi normal dan layak di-gunakan.

\subsection{Uji Heteroskedastisitas}

Uji Heteroskedastisitas bertujuan untuk menguji apakah dalam model regresi terjadi ketidaksamaan varians dari residual satu pengamatan ke pengamatan yang lain. Berikut hasil uji heteroskedastisitas pada tabel 6 .

Tabel 6. Hasil Uji Heteroskedastisitas

\begin{tabular}{|l|c|c|}
\hline \multicolumn{1}{|c|}{ Variabel } & Sig. t & Keterangan \\
\hline Sistem & & \\
Informasi & & \\
Akuntansi & & Tidak terjadi \\
Penjualan dan & 0,924 & Heteroskedastisitas \\
Persediaan & & \\
Barang Dagang & & \\
Berbasis Client & & \\
Server & & \\
Sumber Data : SPSS &
\end{tabular}

Berdasarkan Tabel 6 di atas maka dapat diketahui bahwa nilai signifikansi variabel Sistem Informasi Akuntansi Penjualan dan Persediaan Barang Dagang Berbasis Client Server (X) sebesar 0,924 lebih besar dari 0,05. Artinya tidak terjadi heteroskedastisitas pada variabel Sistem Informasi Akuntansi Pen-jualan dan Persediaan Barang Dagang Berbasis Client Server (X).

\subsection{Analisis Regresi Linier Sederhana}

Untuk mengetahui ada atau tidaknya pengaruh antara Sistem Informasi Akuntansi Penjualan dan Persediaan Barang Dagang Berbasis Client Server terhadap Kinerja Karyawan pada Cipto Jaya Sadel Lamongan, data diolah dengan menggunakan teknik analisis regresi linier sederhana sesuai dengan rumus

$$
\mathrm{Y}=\alpha+\mathrm{bX}+\mathrm{e}
$$


Tabel 7. Hasil Analisis Regresi Linier

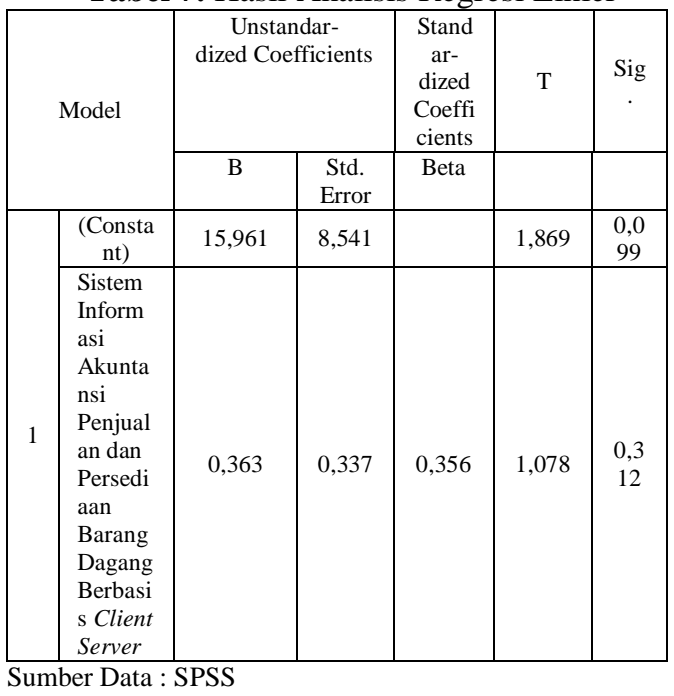

Persamaan regresi linier sederhana diperoleh sebagai berikut : $\mathrm{Y}=15,961+$ $0,363 X+$ e. Nilai koefisien regresi variabel Sistem Informasi Akuntansi Penjualan dan Persediaan Barang Dagang Berbasis Client Server sebesar 0,363 menjelaskan bahwa sistem informasi akuntansi memiliki pengaruh positif terhadap kinerja karyawan. Artinya semakin baiknya penggunaan sistem informasi akuntansi tersebut pada Cipto Jaya Sadel, maka kinerja karyawan akan semakin baik pula.

Untuk mengetahui besarnya pengaruh dua variabel dalam penelitian ini dilihat dari besarnya koefisien determinasi $\left(\mathrm{R}^{2}\right)$ yang disajikan pada Tabel 8 berikut ini
Tabel 8. Koefisien Determinasi $\left(\mathrm{R}^{2}\right)$

\begin{tabular}{|c|c|c|c|c|}
\hline \multicolumn{5}{|c|}{ Model Summary } \\
\hline Model & $\mathrm{R}$ & $\begin{array}{c}\mathrm{R} \\
\text { Square }\end{array}$ & $\begin{array}{c}\text { Adjusted } \\
\text { R Square }\end{array}$ & $\begin{array}{c}\text { Std. } \\
\text { Error of } \\
\text { the } \\
\text { Estimate }\end{array}$ \\
\hline 1 & 0,356 & 0,127 & 0,018 & 5,18146 \\
\hline
\end{tabular}

Dari Tabel 8 dapat diketahui nilai koefisien determinasi (R Square) sebesar 0,127 . Besarnya angka $0,127=12,7 \%$, angka tersebut mengandung arti bahwa sistem informasi kurang berpengaruh ter-hadap kinerja karyawan. Sedangkan sisanya $\quad 87,3 \%$ $(100 \%-12,7 \%)$ dipengaruhi oleh variabel lain diluar model regresi ini.

\subsection{Uji Koefisien Regresi Secara Parsial (Uji t)}

Untuk melihat apakah pengaruh tersebut signifikan atau tidak signifikan, maka nilai koefisien regresi dari variabel Sistem Informasi Akuntansi Penjualan dan Persediaan Barang Dagang Berbasis Client Server (X) akan dilakukan uji signifikansinya. Hipotesis dalam uji t ini adalah sebagai berikut :

1. Ho $=$ sistem informasi

akuntansi penjualan dan persediaan barang dagang berbasis client server $(\mathrm{X})$ tidak berpengaruh sig-nifikan terhadap kinerja karyawan (Y). 
2. $\mathrm{Ha}=$ sistem informasi akuntansi penjualan dan persediaan barang dagang berbasis client server (X) berpengaruh signifikan terhadap kinerja karyawan (Y).

Pengambilan keputusan dalam uji $\mathrm{t}$ adalah sebagai berikut :

1. Ho diterima dan Ha ditolak, jika nilai $\mathrm{t}$ hitung $<\mathrm{t}$ tabel atau jika nilai Sig. $>0,05$.

2. Ho ditolak dan Ha diterima, jika nilai $\mathrm{t}$ hitung $>\mathrm{t}$ tabel atau jika nilai Sig. $<0,05$.

Diketahui nilai $\mathrm{t}$ tabel pada taraf signifikansi $5 \%$ dengan per-samaan berikut :

$$
\begin{aligned}
\mathrm{t} \text { tabel } & =(\alpha / 2 ; \mathrm{n}-\mathrm{k}-1) \\
& =(0,05 / 2 ; 10-1-1) \\
& =0,025 ; 8 \\
& =2,306
\end{aligned}
$$

Berdasarkan hasil analisis regresi diperoleh nilai $\mathrm{t}$ hitung sebesar 1,078 $<\mathrm{t}$ tabel 2,306, dan nilai signifikansinya (Sig.) 0,312>0,05. Maka dapat disimpulkan bahwa Ho diterima dan $\mathrm{Ha}$ ditolak. Artinya Sistem Informasi Akuntansi Pen-jualan dan Persediaan Barang Dagang Berbasis Client Server tidak berpengaruh signifikan terhadap Kinerja Karyawan pada Cipto Jaya Sadel
Lamongan. Hasil penelitian ini didukung pada penelitian Handoko (2015) bahwa pengembangan sistem informasi tidak berpengaruh sig-nifikan terhadap kinerja, disebabkan jumlah responden hanya 34 orang yang mungkin diperlukan pe-nambahan jumlah responden agar penelitian menjadi lebih baik dan berpengaruh signifikan.

\section{PENUTUP}

\subsection{Kesimpulan}

Berdasarkan hasil data dan pengujian maka dapat ditarik kesimpulan sebagai berikut ;

1. Hasil penelitian ini me-nunjukkan bahwa sistem informasi akuntansi penjualan dan persediaan barang dagang berbasis client server tidak berpengaruh signifikan ter-hadap kinerja karyawan pada Cipto Jaya Sadel Lamongan ditunjukkan dari hasil uji t dimana angka Sig. 0,312 $>0,05$. Hal ini disebabkan karena karyawan-karyawan masih belum memiliki keahlian yang cukup untuk menjalankan sistem informasi tersebut. Hasil penelitian ini didukung pada penelitian Handoko (2015) bahwa pengembangan sistem informasi tidak berpengaruh signifikan 
terhadap kinerja, disebabkan jumlah responden hanya 34 orang yang mungkin diperlukan penambahan jumlah responden agar penelitian menjadi lebih baik dan berpengaruh signifikan.

2. $\mathrm{R}$ Square $\left(\mathrm{R}^{2}\right)$ menunjukkan angka sebesar 0,127 , berarti sistem informasi akuntansi penjualan dan persediaan barang dagang berbasis client server hanya mampu mempengaruhi kinerja karyawan sebesar $12,7 \%$. Sedangkan sisanya $87,3 \%$ dipengaruhi oleh variabel yang tidak ada pada penilitian ini.

\subsection{Saran}

Beberapa saran dari penelitian ini adalah :

1. Pemilik Cipto Jaya Sadel diharapkan agar mengadakan pelatihan tentang menjalankan sistem informasi secara rutin kepada karyawan, untuk meningkatkan jenjang pendidikan seluruh karyawannya supaya dapat lebih memahami sistem informasi yang digunakan.

2. Untuk peniliti selanjutnya yang tertarik dengan penelitian ini agar dapat mengembangkan lagi penelitian tentang pengaruh sistem informasi akuntansi penjualan dan per-sediaan barang dagang berbasis client server terhadap kinerja karyawan pada Cipto Jaya Sadel dengan mem-pertimbangkan faktor-faktor lain yang mempengaruhi seperti menambah jumlah responden, jumlah pernyataan kuesioner, dan variabel lainnya.

\section{DAFTAR PUSTAKA}

Arikunto, Suharmisi. 2002. Prosedur Penelitian Suatu Pendekatan Praktek. PT. Rineka Cipta, Jakarta

Assuari, Sofjan. 2004. Manajemen Pemasaran. Rajawali Press, Jakarta

Bodnar, George H. and Wiliam S. Hopwood. 2010. Accounting Information System. $10^{\text {th }}$ edition. Pearson Education Inc., United State Of America

Cokroaminoto. 2007. Membangun kinerja melalui motivasi kerja karyawan.

(Online). (www.cokroaminoto.wordprss.co $\underline{\mathrm{m}}$ ), (diakses 10 April 2018)

Handoko, Septian Dwi. 2015. Analisis Faktor Yang Mempengaruhi Karakteristik Kinerja Sistem Informasi Akuntansi Pada Bank Perkreditan Rakyat Di Surakarta. Naskah Publikasi. Surakarta : Program Studi Akuntansi Fakultas Ekonomi dan Bisnis Universitas Muhammadiyah Surakarta. 
Hidayat, Nanang. 2018. Analisis Pengembangan Sistem Informasi Akuntansi Penjualan dan Persediaan Barang Dagang Berbasis Client Server Pada Cipto Jaya Sadel Lamongan. Skripsi. Lamongan : Program Sarjana Ekonomi Akuntansi Universitas Islam Lamongan.

Indralesmana, Kadek Wahyu dan I.G.N. Agung Suryana. 2014. Pengaruh Penerapan Sistem Informasi Akuntansi Terhadap Kinerja Individu Pada Usaha Kecil dan Menengah di Nusa Penida. EJurnal Akuntansi Universitas Udayana. Volume 8.1; Nomor 14-26.

Jumaili, Salman. 2005. Kepercayaan Terhadap Teknoogi Sistem Informasi Baru Dalam Evalusi Kinerja Individual. Kumpulan materi simposium nasional akuntansi VIII. Solo 15-16 September.

Mulyadi. 2001. Sistem Akuntansi Edisi Tiga. Salemba Empat, Jakarta

Nako, Natalie. 2016. Pengaruh Penerapan Sistem Informasi Akuntansi Terhadap Kinerja Individu Pada Balai Pemantapan
Kawasan Hutan Wilayah XI Jawa-Madura. Tesis. Yogyakarta: Program Studi Akuntansi Fakultas Ekonomi Universitas Atma Jaya Yogyakarta

Sugiyono, 2010. Metode Penelitian Pendidikan Pendekatan

Kuantitatif, Kualitatif, dan $R \& D$. Alfabeta, Bandung

Sugiyono. 2014. Metode Penelitian Pendidikan Pendekatan Kuantitatif, Kualitatif dan R\&D. Alfabeta, Bandung

Syafrizal, Melwin. 2005. Pengantar Jaringan Komputer. Andi, Yogyakarta. 